University of Louisville ThinkIR: The University of Louisville's Institutional Repository

Electronic Theses and Dissertations

$5-2016$

\title{
The colored librarian : Thomas F. Blue and the Louisville Free Public Library's Colored Department, 1905-1935.
}

Jacob Carlton Burress

University of Louisville

Follow this and additional works at: https://ir.library.louisville.edu/etd

Part of the Social History Commons

\section{Recommended Citation}

Burress, Jacob Carlton, "The colored librarian : Thomas F. Blue and the Louisville Free Public Library's Colored Department, 1905-1935." (2016). Electronic Theses and Dissertations. Paper 2420.

https://doi.org/10.18297/etd/2420

This Master's Thesis is brought to you for free and open access by ThinkIR: The University of Louisville's Institutional Repository. It has been accepted for inclusion in Electronic Theses and Dissertations by an authorized administrator of ThinkIR: The University of Louisville's Institutional Repository. This title appears here courtesy of the author, who has retained all other copyrights. For more information, please contact thinkir@louisville.edu. 
THE COLORED LIBRARIAN:

THOMAS F. BLUE AND THE LOUISVILLE FREE PUBLIC LIBRARY'S COLORED DEPARTMENT, 1905 - 1935

\author{
By \\ Jacob Carlton Burress \\ B.A., University of Louisville, 2012
}

\begin{abstract}
A Thesis
Submitted to the Faculty of the College of Arts and Sciences of the University of Louisville in Partial Fulfillment of the Requirements for the Degree of
\end{abstract}

\author{
Master of Arts \\ in History
}

Department of History

University of Louisville

Louisville, Kentucky

May 2016 
Copyright 2016 by Jacob Carlton Burress

All Rights Reserved 

THE COLORED LIBRARIAN:

THOMAS F. BLUE AND THE LOUISVILLE FREE PUBLIC LIBRARY'S COLORED DEPARTMENT, 1905 - 1935

By

Jacob Carlton Burress

B.A., University of Louisville, 2012

A Thesis Approved on

April 4, 2016

by the following Thesis Committee

Lara Kelland, Thesis Director

Tyler Fleming

Cate Fosl 


\title{
DEDICATION
}

\author{
To my grandparents \\ Harvie Edmond and Nell Katherine (Dawson) Burress \\ $\&$ \\ Jack Madison and Ima (Wilson) Bybee
}

who supported and nurtured the intellectual curiosity of an inquisitive child, for their endearing love and encouragement, and whom I hope to make proud one day 


\section{ACKNOWLEDGEMENTS}

This thesis would not have been possible without the help and encouragement of numerous people. The first of which I would like to thank is Christopher Williams, my high school A.P.U.S.H. teacher. He opened the door to historical inquiry that has guided me since. Secondly, I would like to thank Dr. Thomas C. Mackey who pushed me harder than ever before in his classes and with his constant reminder to "press on." These words were constantly ringing in my ears during the writing process. Thirdly, I would like to thank Dr. Brad Bowman for his humor, wit, and reminding me that my "think piece" would one day come to fruition.

My time in the History Department would not be the same, nor as enjoyable, without Lee Keeling and Robin Carroll. These two ladies allowed me to kill time, share some laughs, and catch-up on the latest gossip.

To my fellow graduate students - Wes Cunningham, Alex Covington, Hannah O’Daniel, Matt Holdzkom, Javier Bonilla, Danny Michael, and Carl Creason - thank you for the wonderful seminar discussions, office chats, and free food. You all have made this journey worthwhile.

I would also like to thank my thesis committee - Dr. Lara Kelland, Dr. Tyler Fleming, and Dr. Cate Fosl - who provided wonderful comments and criticisms that only strengthened the finished project immensely. A special "thank you" to my committee chair, Dr. Lara Kelland, cannot be properly written or expressed. I cannot repay you for the numerous hot chocolates, rich discussions, Minnesotan humor, and end-of-the- 
semester potlucks. You have opened my eyes to new philosophies, inquiries, thoughts, and helped in expanding my worldview. For this, I am forever in your debt, Lara!

To Neal Singleton, Keith Cheatham, and Brandon Davidson, who heard me complain and question graduate school, thank you for reminding me "it will be worth it in the end." Your friendship means the world to me.

Lastly, to my family, thank you. My sisters, Brittney and Kelsey, always asked how my thesis was coming along. Though it took longer than I intended, it is now complete. My brother-in-law, Corey, always supported me in his own, quiet way. My nephew, Maddox, provided me with many moments to free my mind from this project and enjoy the small things. To my parents, Mark and Marla, who watched me work late into the night, buy large stacks of books, and countless office supplies, your words of support were always felt and noticed. 


\begin{abstract}
THE COLORED LIBRARIAN:

THOMAS F. BLUE AND THE LOUISVILLE FREE PUBLIC LIBRARY'S COLORED

DEPARTMENT, $1905-1935$

Jacob Carlton Burress

April 4, 2016

This thesis examines the role of Reverend Thomas F. Blue and the Colored Department at the Louisville Free Public Library played in generating social uplift for African Americans in Louisville, Kentucky in the first third of the twentieth century. Working from the philosophical framework of intellectuals Booker T. Washington and W.E.B. Du Bois, Blue created the first free Colored Library Department in the nation and used that department as a nexus in Louisville's African American community. The Introduction outlines the central argument of the paper and sets up the intellectual debates between Washington and Du Bois. The second section dives into these intellectual debates and the impetus for the Colored Department's founding. The third section examines Blue and his ideas of how the library should operate and function in society. In the Conclusion, Blue provided an area for the fostering of racial uplift and social progress in the city through the Library's books and reference materials, educational programs, and community spaces. As part of the alternative thesis, there are two podcast episodes that explore education in Louisville around the Library's founding and Blue's professionalization of library science for African Americans.
\end{abstract}


TABLE OF CONTENTS

PAGE

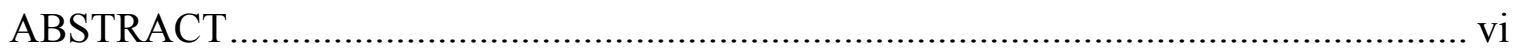

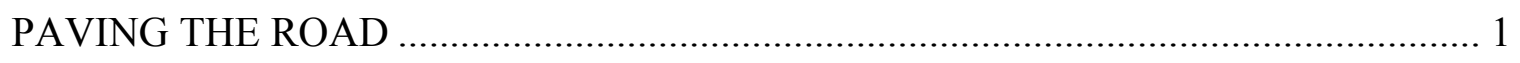

FOUNDING OF THE COLORED LIBRARY DEPARTMENT …………………........ 4

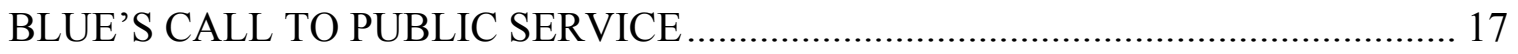

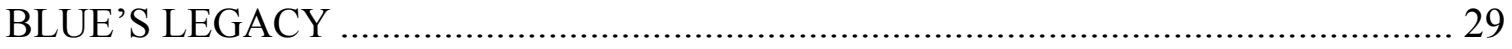

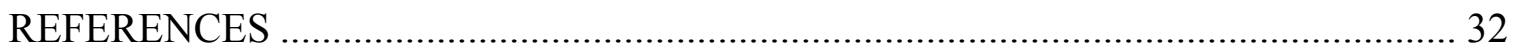

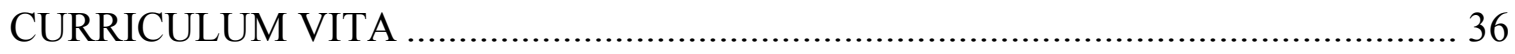


PAVING THE ROAD:

\section{THE NEED FOR THE COLORED LIBRARY DEPARTMENT}

In 1905, the Louisville Free Public Library system established the Western Colored Library Branch in Louisville, Kentucky. Nine years later in 1914, the library system established the Eastern Colored Library Branch, creating the first Colored Library Department in the United States. ${ }^{1}$ Headed by African American Thomas Fountain Blue, the Colored Department provided blacks in Louisville with a separate area to advance their education, engage in community affairs, and to cultivate social uplift. With the help of local African American educator and activist Albert E. Meyzeek, Blue worked for African American inclusion into the broader American society. Under Blue's direction, the Colored Department of the Louisville Free Public Library offered a place for such advancement. The formation of the Colored Department and Blue's activism arose, in part, from the earlier foundations of African American educators and activists Booker T. Washington and W.E.B. Du Bois and the marrying of their two ideologies into the one, workable synthesis within the Colored Library Department.

In the late nineteenth and early twentieth centuries, Booker T. Washington and W.E.B. Du Bois promulgated two differing theories of social uplift for their fellow

\footnotetext{
${ }^{1}$ Lillian Taylor Wright, "Thomas Fountain Blue: Pioneer Librarian, 1866-1935," Masters thesis, Atlanta University, 1955, 50.
} 
African Americans in American society. Du Bois' theory acted as a continuation of the Washington's ideas. The elder of the two, Washington advocated for African Americans to work within the existing structures and framework of American society to better themselves in his seminal work, Up From Slavery. Washington believed whites would never fully acclimate to blacks gaining equality in society. As such, Washington felt that blacks needed to not overthrow the de jure system of segregation but to use it as best they could to gain a footing in society. ${ }^{2}$

This idea differed from W.E.B. Du Bois, who advanced Washington's ideas further. For Du Bois, there needed to be a trained, educated, and mobilizing group of likeminded individuals driving the push for social change. Dubbed the "Talented Tenth" by Du Bois, as they represented one in ten who could actively push for such social change and progress, the Talented Tenth would act as the catalyst for ending the system of segregation in the United States. By first presenting an educated, civilized, and capable association of African Americans to white Americans, the Talented Tenth could then work to end segregation. ${ }^{3}$

One such example of black leadership as a manifestation of Du Bois' Talented Tenth was Thomas Blue. Thus far, Blue's role at the Louisville Free Public Library has been overlooked by historians. While at the Colored Library, Blue oversaw three important changes both within the library system and in the greater library field. First, Blue established the first colored library department in the United States. As such, Louisville's Colored Library Department served as a model for other colored

\footnotetext{
${ }^{2}$ Booker T. Washington, Up From Slavery (New York: Airmont Books, 1967).

${ }^{3}$ W.E.B. Du Bois, "The Talented Tenth," The Negro Problem: A Series of Articles by Representative American Negroes of To-Day. (New York: James Pott \& Co., 1903).
} 
departments across the nation, particularly in the South. ${ }^{4}$ Second, as Head of the Colored Department, Blue implemented an apprenticeship course for African Americans wishing to enter the library field. This training class was at the forefront of the emerging field of library science and trained dozens of African Americans who took what they learned and applied it in their own libraries. Third, Blue was committed to cultivating the library as a space in service to the community. This public space provided educational resources, programming, and group meetings to generate social uplift for African Americans.

Throughout their professional lives, Washington and Du Bois offered two different models for social uplift for African Americans in American society. It was through a blend of these two methods, however, that Thomas F. Blue and the Colored Department at the Louisville Free Public Library pushed for education, community engagement, and social uplift for African Americans in Louisville during the early twentieth century. These efforts would be tough given the de jure Jim Crow segregation in the South and the resentment toward Du Bois' Talented Tenth by the white society.

\footnotetext{
${ }^{4}$ Michael Fultz, "Black Public Libraries in the South in the Era of De Jure Segregation," Libraries \& the Cultural Record 41 (Summer 2006): 344.
} 


\section{FOUNDING OF THE COLORED DEPARTMENT:}

\section{THOMAS F. BLUE AND RACIAL UPLIFT}

While working in a West Virginia coal mine, a young laborer overheard two of his fellow miners talking about a school "for coloured people in Virginia." To the eavesdropper, this conversation sparked a life-long interest in education for African Americans. As the young Booker T. Washington recalled, "this was the first time that I had ever heard of anything about any kind of school or college . . . than the little coloured school in our town." Washington continued to work at the coalmine a few more months before he traveled to the Hampton Normal and Agricultural Institute in Virginia. At Hampton, Washington realized education was one of the principal means of social equality and racial uplift for African Americans in the wider American society. For most African Americans, universities and colleges were not financially possible. However, in the late nineteenth and early twentieth centuries, the growing number of public libraries in the United States offered a space and environment for the ideas of Washington and others to manifest. In Louisville, Kentucky, these ideas came to fruition through the establishment of the Louisville Free Public Library's Western Colored Library branch in 1905.

\footnotetext{
${ }^{5}$ Washington, 37.
} 
In Louisville, Kentucky, the philosophy of racial uplift, manifested by way of education, most resonated with local African American leaders like Reverend Thomas Fountain Blue and Albert E. Meyzeek. For Blue and Meyzeek, education provided the most effective means for social uplift. In order for that uplift to occur, schools played a critical educational building block. It was in the schools were educators taught students these principles and philosophies. Other leaders identified libraries as another institutional need for Black education. It was in the library were the students transformed the education they received by their teachers into a practical theory. The Louisville Free Public Library system in the early nineteenth century offered young African Americans a year-round place to learn and grow, processes which resulted in the uplift of the Black community.

In embracing an education mission for the social uplift and equality of African Americans, Washington was not alone. W.E.B. Du Bois, at first a protégé of Washington's, advanced these ideas and called for a "talented tenth," a leadership class in the Black community comprised of "upward-mobility [minded] middle-class Africans Americans" whose optimism generated better social conditions for themselves. ${ }^{6}$ For $\mathrm{Du}$ Bois, this group of African Americans came from an educated and higher socioeconomic background and were better suited to represent the race in society to their white counterparts. Like Washington, education and libraries played an important role in nurturing this social uplift.

Yet each of these men gained widespread, national attention. W.E.B. Du Bois' dubbed the "Talented Tenth," the "leadership of the Negro race in America by a trained

\footnotetext{
${ }^{6}$ David Levering Lewis, ed., W.E.B. Du Bois: A Reader (New York: Henry Holt and Company, 1995), 5 .
} 
few" to be the best way to better African Americans in American society. ${ }^{7}$ Du Bois wrote:

Men we shall have only as we make manhood the object of the work of the schools - intelligence, broad sympathy, knowledge of the world that was and is, and of the relation of men to it - this is the curriculum of that Higher Education which must underlie true life. On this foundation we may build bread winning, skill of hand and quickness of brain, with never a fear lest the child and man mistake the means of living for the object of life. ${ }^{8}$

For Du Bois, this trained Talented Tenth would lead their fellow African American breathern forward as they represented the trained and talented individuals who must "work not simply as individuals," but as a greater social force for change and social advancement. ${ }^{9}$ In re-evaluating the model of the Tenth near the end of his life, Du Bois then championed the "Guiding Hundredth," a newer and larger outgrowth of the Tenth. This Hundredth was the realization and fulfillment of the Tenth's ultimate vision for African Americans. ${ }^{10}$ The democratization of the Talented Tenth into the Guiding Hundredth allowed for all African Americans to partake in generating social uplift and creating a synthesis within the race. ${ }^{11}$ Concentrating in large, urban areas like New York, Philadelphia, and Washington, D.C., Du Bois' message gained the admiration of thousands of African Americans, including Blue and Meyzeek in Louisville, Kentucky.

As the years wore on, differences between Washington and Du Bois arose. Early in their professional careers, Booker T. Washington and W.E.B. Du Bois shared a similar goal in advancing their race in society. However, both men took different

\footnotetext{
${ }^{7}$ W.E.B. Du Bois, “The Talented Tenth: Memorial Address," Boulé Journal 15 (October 1948): 3.

${ }^{8}$ W.E.B. Du Bois, "The Talented Tenth," 35.

${ }^{9}$ Du Bois, Boulé, 7.

${ }^{10}$ Ibid., 13.

${ }^{11}$ Reiland Rabaka, "W. E. B. Du Bois's Evolving Africana Philosophy of Education,” Journal of Black Studies 33 (Fall 2003): 416.
} 
approaches to meet this end. Washington stressed working within the already established system of segregation in gaining an education and working with whites to advance the race. Du Bois believed segregation was the root of the problem and needed to be overcome by eliminating it altogether. Washington's framework was a bottom up model while Du Bois fostered a top down, or elitist approach. In pushing Washington's ideas farther, Du Bois represented a continuation of the work Washington started.

Yet men understood white attitudes toward the "uncivilized Negro" needed changing. When on his 1909 tour in the South in promoting the Tuskegee Institute, Washington recognized he and the others on his tour would be scrutinized and judged by southern whites to be inferior. Those with him on the tour - seen as members of Du Bois' Tenth - represented that blacks were equal to their white counterparts in showing the progress made by Washington, Du Bois, and others. ${ }^{12}$ These "successful, educated, well-dressed, well-spoken, economically secure, and respectable" men on the tour with Washington conducted themselves in such a manner to discriminate against the perceived image of African Americans as uncivilized. Any conduct to the "contrary would have added fuel to arguments of black underdevelopment and degeneration" in the minds of whites. ${ }^{13}$ These shared ideas were not to last.

As early as 1900, a distancing began between Washington and Du Bois. In 1900, Washington founded the National Negro Business League as a more direct

\footnotetext{
${ }^{12}$ David H. Jackson, Jr., Booker T. Washington and the Struggle Against White Supremacy: The Southern Educational Tours, 1908-1912 (New York: Palgrave Macmillan, 2008), 180. Those on tour with Washington, though not formally of Du Bois' Talented Tenth, represented the civilized African American in white eyes to promote against the idea of an "uncivilized" African American.

${ }^{13} \mathrm{Ibid}$.
} 
instrument to deal with the economics of blacks. ${ }^{14}$ Washington served as the League's president from its founding until his death in 1915. Although headed by Washington, the League was the brainchild of Du Bois. In 1899, Du Bois organized a conference on African Americans in business. ${ }^{15}$ In a report drafted after the conference, Du Bois argued against one-sided developments that crippled black economic freedoms and economic growth. ${ }^{16}$ These one-sided developments usually benefited whites either through the loan process or acquisition of goods and services. Blacks were still subjugated to whites in the business world. In his report, Du Bois called for African Americans to "buy black" with "Negro money for Negro merchants," even as he lamented such one-sided developments. ${ }^{17}$ To balance these one-sided enterprises, $\mathrm{Du}$ Bois reasoned the economic impact of Blacks buying from Black merchants was the true way to gain economic independence from white business interests. Du Bois argued for educational training against white special interests in Black economics as the vanguard to economic liberties in black business interests.

In 1905, while Washington and Du Bois were debating each other on the national stage over their growing and expanding philosophies for African Americans in American society, a young Black minister, Reverend Thomas Fountain Blue, accepted a position as head librarian of the newly created Colored Western Library Branch in Louisville, Kentucky. On the morning of September 23, 1905, Blue entered three rented rooms in a house in West Louisville. Reverend Blue's excitement over this new library

\footnotetext{
${ }^{14}$ Louis R. Harlan, Booker T. Washington: The Making of a Black Leader, 1856-1901 (New York: Oxford University Press, 1972), 265-266.

${ }^{15}$ Ibid., 266.

${ }^{16}$ Ibid., 267.

${ }^{17}$ W.E.B. Du Bois, ed., The Negro in Business: Atlanta University Publications, No. 4 (Atlanta, 1899), 12, 50.
} 
stemmed from the fact the new branch he was now in charge of was "the first free public library for colored readers with colored attendants." ${ }^{, 18}$ Before Blue officially assumed his post of the Western Branch Library, he hired a small staff for the library. Like Reverend Blue, his entire staff consisted of African Americans. This gave African Americans in West Louisville their own library for education, learning, and reading, an institutional development that mirrored the strategies of Washington by working within the restrictions of segregation.

The opening of the segregated library offered an important educational opportunity for Blacks in the city. The Louisville Times, a local white newspaper, immediately proclaimed, "the library will uplift [the] race" in the area. ${ }^{19}$ Those complimentary words from a white newspaper reflected the community's support and commitment to the endeavor. Prior to the library's existence, there were no comparable resources available to African Americans in the area. With the library and its services, residents gained access to the educational instruments advocated by Booker $\mathrm{T}$. Washington to become part of W.E.B. Du Bois' Talented Tenth. The new library contained "three rooms, large, airy; floors covered with linoleum. A complete card catalogue system was installed. The reference works contained the latest editions of the Century Dictionary, Webster's Dictionary, Encyclopedia Americana, and Charles Warner's Library."20 Through the library and its resources, previously educationally marginalized African Americans in the area gained the tools and resources for learning. By November 1905, just three months after opening, reports indicated 4,132 visitors and

\footnotetext{
${ }^{18}$ Wright, 46.

${ }^{19}$ Louisville Times, September 28, 1905.

${ }^{20}$ Ibid.
} 
1,545 volumes borrowed during the month. ${ }^{21}$ The library was certainly thriving, but was strained by the demands placed on it by its patrons. The staff could not keep pace with the community's interest in the library and its services. ${ }^{22}$

The popularity of the new library forced administrators to expand capacity. In 1908, the Western Branch library moved into its new, permanent building at the southwest corner of $10^{\text {th }}$ and Chestnut Streets. This building was just west of the Library's main branch at $3{ }^{\text {rd }}$ Street and Broadway in downtown Louisville. This new library building opened as Louisville's first Carnegie library building. In the late nineteenth century and early twentieth century, steel magnate Andrew Carnegie began donating money and resources establishing libraries across the country. He built libraries in communities where none previously existed. Through Carnegie's donations and support, millions of Americans gained educational resources they never had the opportunity beforehand. It also represented a shift in some whites' attitudes toward African Americans and giving them equal opportunities. To that end, a sign over the doorway at the Western Branch Library read "Knowledge is Power." 23

The enthusiastic demand that patrons placed on the Western Colored Branch led the library system to open a second Carnegie library just six years later in 1914. This new Carnegie library housed the second public library in Louisville solely dedicated to African Americans. ${ }^{24}$ The Eastern Branch was located in the Smoketown neighborhood

${ }^{21}$ Louisville Herald, December 7, 1905.

${ }^{22}$ Second Annual Report of the Board of Trustees of the Louisville Free Public Library for the Year Ending August 31, 1906, Reverend Thomas F. Blue Papers, Louisville Free Public Library.

${ }^{23}$ Ibid.

${ }^{24}$ Wright, 48. 
at the southeast corner of Hancock and Lampton Streets. ${ }^{25}$ Smoketown lies east of downtown Louisville, north of Germantown and Schnitzelburg along Eastern Parkway, and west of the Highlands neighborhood along Bardstown Road. Like residents of West Louisville, Smoketown residents were underserved by the city. Dominated by lower socioeconomic African Americans, many began calling for a colored library in the area shortly after the opening of the Western Colored Library. The success of the Western Colored Library created uplift opportunities in the Russell neighborhood, but for residents of Smoketown, it proved too far away for beneficial use. At the urging of Reverend Blue and others, the Library Trustees "established a second colored branch in the eastern part of the city," which opened on January 28, 1914 to serve those residents. $^{26}$

With the addition of the Eastern Colored Library in the Louisville Free Public Library system, Reverend Blue formed a "Colored Department" within the library system, the first of its kind in the nation. ${ }^{27}$ By 1916, two years after the Eastern Colored Branch opened, Thomas Jesse Jones estimated there were only fifteen public libraries in the South providing services solely for African Americans, with Louisville claiming two of them. Most of these libraries were in the Deep South with Nashville, Tennessee being the closest in proximity to Louisville's library. ${ }^{28}$ Louisville's unique location and

\footnotetext{
${ }^{25}$ Cheryl Knott Malone, “Louisville Free Public Library's Racially Segregated Branches, 1905-1935," Register of the Kentucky Historical Society 93 (Spring 1995): 170.

${ }^{26}$ Thomas Fountain Blue, "Colored Branch Library Work in Louisville” n.d., Reverend Thomas F. Blue Papers, Louisville Free Public Library.

${ }^{27}$ Wright, 50.

${ }^{28}$ Thomas Jesse Jones, Negro Education: A Study of the Private and Higher Schools for Colored People in the United States, 2 vols. (Washington, D.C.,: United States Bureau of Education, 1917), 1: 173-5.
} 
social make-up as a border city played a large part in the growth and proliferation of its Colored Department, a significant institutionalization for black resources, if segregated, within the civic structure of the city.

Louisville occupied at the time, and in many ways still does, a unique geographic position. As Tracy K'Meyer and others have argued, Louisville is simultaneously a Southern, Northern, and Midwestern city. ${ }^{29}$ To those in the North, Louisville's position as south of the Ohio River makes it a Southern city. To those in the South, Louisville acts as the northern border to the South, providing a transitional place for the two cultures. Its Midwestern status comes from Kentucky being the first state admitted to the Union lying west of the Appalachian Mountains. Those early settlers adopted the fierce and rugged spirit often seen from those in the Midwest. During the Civil War, the city of Louisville favored with the North to protect its commercial interests. The rest of the state, though not officially, held sympathetic ties to the South. Lying in this area between three distinct regions, Louisville's black population was relatively smaller in number yet had high literacy rates compared to other southern states. ${ }^{30}$ Reverend Thomas Blue and Albert E. Meyzeek thrived in Louisville's unique geographic placement and fertile environment for Black leadership, owing in part to its northern ties. Both men attended college - Meyzeek at Indiana University and Blue at Hampton Institute - and moved to Louisville to build lives for themselves and better the lives of their fellow African Americans.

\footnotetext{
${ }^{29}$ Tracy E. K'Meyer, Civil Rights in the Gateway to the South: Louisville, Kentucky 1945-1980 (Lexington, Kentucky: University Press of Kentucky, 2009), 1-15.

${ }^{30}$ Malone, "Louisville Free Public Library's Racially Segregated Branches, 1905-1935," 162.
} 
Given the unusual and unprecedented position for a man of color, what prompted the Louisville Free Public Library to offer Blue this new position? Leadership roles had previously gone to white men who often had had men and women of color working under him. Beyond Louisville's unique culture as a border city, national cultural shifts of the Progressive Era also aided Blue in his professional advancement. The decades prior had seen considerable change in lives of millions of American workers, women, and laborers. The formation of unions, trade organizations, social groups, and racial associations reshaped American thinking and began shifting the social hierarchy previously dominated by white men. ${ }^{31}$ Echoing Progressive Era values of social uplift, the philosophies and teachings of Booker T. Washington and W.E.B. Du Bois began penetrating into the American heartland through figures like Blue and Meyzeek.

Albert E. Meyzeek, a local school principal, was one of those that demanded a black library for African Americans in Louisville. Meyzeek received his master's degree from Indiana University and moved to Louisville in the mid 1890s, later joining the Banneker Reading Circle with his wife. This group, like many others in the country, promoted "self-culture" around the turn of the century. This self-culture taught African American culture, identity, history, and consciousness to blacks by blacks instead of by whites. As a way of educating as many people as possible, the Banneker Reading Circle acted in a similar fashion to a book club, where members read aloud books to the other members. ${ }^{32}$ Later the group would continue to meet at the Western Colored Library

\footnotetext{
${ }^{31}$ Felix Gilbert and David Clay Large, The End of the European Era, 1890 to the Present (New York: W.W. Norton, 1991), 15-27.

${ }^{32}$ Wayne A. Wiegand, Part of Our Lives: A People's History of the American Public Library (New York: Oxford University Press, 2015), 108.
} 
alongside other children reading circles. ${ }^{33}$ Even when school was not in session, Blue noted the regular meetings of this group in his annual reports. ${ }^{34}$

While principal at Central High School, Louisville's only black high school, Meyzeek took his senior students to the main public library to conduct research on class projects. Central High School had no library of its own at the time, except for a small reference collection that Meyzeek established in his office. After a few visits, his students were turned away and denied access to the public library by the library staff. No policy existed at the time denying blacks the right to use the library; but the staff and patrons of the library felt uneasy that African Americans kept returning to the library. Their concern stemmed from the idea that black students using the library for an educational purpose would turn into patrons of the library for personal and leisurely use. The white staff and patrons did not want Meyzeek's students and others to loiter at the library. Incensed by his students' humiliation, Meyzeek actively campaigned for the library to provide a branch for African Americans. His efforts were successful with the opening of the Western Colored Branch in $1905 .^{35}$

Before his library campaign, Albert E. Meyzeek worked tirelessly for equal accommodations for African Americans in Louisville. In 1892, after years of lobbying and organizing, he helped establish the colored YMCA. The organization of a colored

\footnotetext{
${ }^{33}$ Louisville Free Public Library, Colored Branch, Louisville Free Public Library: A Brief Illustrated Description of the New Building Together With Some Interesting Figures Concerning Its Cost, Its Equipment, and Its Use (Louisville, Kentucky: 1912), 8.

${ }^{34}$ Thomas Fountain Blue, Annual Report of the Western Colored Branch for the year ending August 31, 1913, Reverend Thomas F. Blue Papers, Louisville Free Public Library

${ }^{35}$ Malone, “Louisville Free Public Library's Racially Segregated Branches, 1905-1935," 162-163.
} 
YMCA predated the famous judicial opinion of Plessy v. Ferguson of 1896. In Plessy, the Supreme Court's 7-1 opinion established the doctrine of "separate but equal" accommodations for African Americans. In doing so, the Supreme Court legalized segregation in the public sphere for the next six decades. ${ }^{36}$ In the two decades following the colored YMCA's establishment, Meyzeek served on the association's management committee. There he met, worked along side, and developed a friendship with Reverend Thomas Blue. Fortunate for the friendship, "it was Meyzeek's recommendation that secured Blue's position as head of the Western Branch." ${ }^{37}$ Yet even with Meyzeek's friendship, tutelage, and educational reform history, Reverend Blue faced many challenges in offering educational services and opportunities for African Americans in West Louisville.

The political and social thinking in the preceding two centuries in the United States stymied much of the structural progress for persons of color. Initially excluded from the Declaration of Independence and the Constitution, African Americans were not considered as citizens of the United States. Not until the $13^{\text {th }}, 14^{\text {th }}$, and $15^{\text {th }}$ amendments, known collectively as the Reconstruction Amendments, did African Americans gain the guaranteed citizenship, voting rights, and liberties, freedoms that had been previously withheld from them. It was the first step toward equal standing before the law and American society at large. ${ }^{38}$ With its Plessy decision, the Supreme

\footnotetext{
${ }^{36}$ Charles A. Lofgren, The Plessy Case: A Legal-Historical Interpretation (New York: Oxford University Press, 1987), 5-9.

${ }^{37}$ Malone, 163.

${ }^{38}$ Michael Vorenberg, Final Freedom: The Civil War, the Abolition of Slavery, and the Thirteenth Amendment (New York: Cambridge University Press, 2001), 167.
} 
Court thwarted much of the progress made by the Reconstruction Amendments. ${ }^{39}$ The system of Jim Crow, with no governmental checking, soon spread from the South throughout most of the United States. This de facto system of segregation and discrimination in the South lasted long after Blue's 1935 death. Yet it was during this time of written expansion of African American rights and systematic racism that Blue came to run Louisville's first Colored Library. In the two centuries prior to Blue's professional career, the idea of an African American holding any job of means was unheard of and, in some places, forbidden by law. As the two centuries materialized, progress was indeed made for African Americans in American society.

${ }^{39}$ Lofgren, 4-7. 


\section{BLUE’S CALL TO PUBLIC SERVICE: \\ MINISTER TURNED LIBRARIAN, ACTIVIST, AND RACIAL UPLIFTER}

The second child of former slaves, Thomas Fountain Blue was born on March 6, 1866 in Farmville, Virginia. Thomas was the second child of three children born to Noah Hedgeman Blue and Henry Ann Crawley. He had one older sister, Alice Linwood Blue, and one younger brother, Charles Sumner Blue. ${ }^{40}$ His maternal grandmother raised Blue and his siblings after the death of their mother at an early age. ${ }^{41}$ Little is known of Blue's early life before he entered the Hampton Institute in 1885 . He attended Hampton until his graduation in 1888 at which point he spoke to his graduating class:

God has bountifully blessed us, so let us endeavor to show our gratitude to Him by devoting our energy to the betterment of our people, for when we help out fellow man, we are working for God. As we enter upon the duties of life, let our every movement be characterized by unity of aim, unity of purpose and unity of act; then and not till then will the dark cloud of ignorance, superstition and intemperance disperse, and education, intelligence, and virtue spread over our land. $^{42}$

Like fellow Hampton Institute graduate Booker T. Washington before him, Blue realized the role education played in bettering the plight of African Americans after the Civil War. For Blue and other uplift-minded African Americans, education stressed

\footnotetext{
${ }^{40}$ Letter from Mary E. Blue, widow of Charles Sumner Blue, to Thomas F. Blue, Jr., June 16, 1953, Reverend Thomas F. Blue Papers, Louisville Free Public Library.

${ }^{41}$ Ibid.

${ }^{42}$ Thomas Fountain Blue, "Farewell Address" delivered at Hampton Institute, 1888, Reverend Thomas F. Blue Papers, Louisville Free Public Library.
} 
acquiring knowledge and understanding, which in turn allowed the individual to assess and evaluate his or hers surroundings better and make informed interventions into racial struggles.

Following graduation, Blue taught high school in Virginia for a short time before enrolling in the Richmond Theological Seminary in 1894. In 1896, he graduated with a Bachelors of Divinity degree. ${ }^{43}$ Despite his theological training, Blue never held a pastorate. He did, however, on many occasions give guest sermons at various churches throughout his life, with some of "his sermons hav[ing] survived in manuscript form."44 When war erupted during the Spanish American War in 1898, Blue served as a secretary for the Young Men's Christian Association (YMCA) for one year. At the time, the YMCA operated a separate Colored Men's Department in addition to the regular white YMCA. The Colored YMCAs focused on building a sense of community among the various YMCAs. ${ }^{45}$ Attached to the Sixth Virginia Regiment Volunteers while stationed at Camp Poland in Knoxville, Tennessee and Camp Haskell in Macon, Georgia, Blue realized social factors affected all men, regardless of color. ${ }^{46}$ Speaking of his time in the service Blue commented, "here [I] was furnished an opportunity to study men, of all classes, of all walks of life" at the same time and learned the value education played in

\footnotetext{
43 Thomas Fountain Blue, “A Hamptonian as Librarian," Southern Workman 52 (July 1923): 368.

${ }^{44}$ Wright, 5. No such sermons were found in the Blue Papers at the LFPL. When Wright wrote her Masters in Library and Informational Science (MLIS) thesis, these sermons may well have been in the possession of a family member, however, they were not found by this author.

${ }^{45}$ Nina Mjagkij, Light in the Darkness: African Americans and the YMCA, 1852-1946 (Lexington, Kentucky: University Press of Kentucky, 1994), 39.

${ }^{46}$ Wright, 6.
} 
creating learned society. ${ }^{47}$ Nearly two decades later, when the United States declared war on Germany in 1917, Blue again enlisted. This time stationed at Camp Taylor in Louisville, Kentucky, Blue was reassigned to the Colored YMCA. While at Camp Taylor, Blue taught classes to the African American soldiers. He commented, "I have two hundred men in my educational classes. Most of these cannot read and write. The work here is an interesting experience and an opportunity worth while for real, helpful service." 48

Blue's first stint with the YMCA during the Spanish American War marked the first position in a public service career spanning four decades. In 1899, Reverend Blue accepted the position to head Louisville's first Colored Branch of the YMCA. Other branches already operated in other cities but following the mandate in the Plessy decision, Louisville built its own colored YMCA. While there, Blue nurtured a communal, safe, and healthy environment for blacks to become active, healthy, and prosperous citizens, values all promoted by Progressive Era reformers. He served on various committees during his time at the YMCA and was elected Treasurer every year. ${ }^{49}$ Soon, others outside of the YMCA began noticing the work and dedication exhibited by Blue.

In 1905, after six years with the YMCA, Blue resigned and accepted the position of librarian for the new Colored Branch of the Louisville Free Public Library. Recall, Blue had no training in library science. The emerging field of library science was still

${ }^{47}$ Address of Thomas F. Blue at the Fiftieth Anniversary of the founding of Wayland Institute, Washington D.C. and Richmond Theological Seminary, Richmond, VA, June 2, 1915, Reverend Thomas F. Blue Papers, Louisville Free Public Library.

48 Thomas Fountain Blue, Southern Workman 47 (July 1918): 367-368.

${ }^{49}$ Blue, "A Hamptonian as Librarian," 368. 
embryonic in nature at that time. Thirty years before, in 1876, Melvil Dewey published his cataloguing system for books. ${ }^{50}$ This system, Dewey Decimal System, served as the basis for cataloguing the books and periodicals at the Louisville Free Public Library. ${ }^{51}$ Blue's education at Hampton and Richmond Theological Seminary geared Blue toward a life of the soul, not the mind. What leaders at the Library saw in Blue was his commitment to his fellow African American, his dedication to his community, and his desire for equality for African Americans. Recognizing Blue's substandard training as a librarian, white officials at the Library instructed him on the inner-workings of the library system. Blue later recalled he was in "need of special preparation for the work before taking charge," and was therefore "given special instruction by Heads of Departments at the Main Library" before he started. ${ }^{52}$ The instruction paid off, as Blue spent the next thirty years with the Library. However, Blue never forgot white librarians trained him to administer a black library. Several years later, once firmly in his new post, Blue began an apprenticeship course for other black professionals wishing to enter the library field.

Once in his new position, Blue quickly began accumulating resources for his branch. Blue asked the Trustees for money to purchase more books. They eventually consented and Blue bought more books for his patrons' use. His staffed created a detailed inventory of the branch's holding for adults and children. The adult section contained books on history, philosophy, sociology, gardening, poetry, literature,

\footnotetext{
${ }^{50}$ Melvil Dewey, A Classification and Subject Index for Cataloguing and Arranging the Books and Pamphlets of a Library (Amherst, Massachusetts: 1876).

${ }^{51}$ Thomas Fountain Blue, "Public Library Work Among Colored People" n.d., Reverend Thomas F. Blue Papers, Louisville Free Public Library.

${ }^{52}$ Ibid..
} 
business, and numerous other topics. ${ }^{53}$ Such titles included W.E.B Du Bois's Souls of Black Folks, Booker T. Washington's Up From Slavery, Paul Laurence Dunbar's collections of poems, Benjamin Brawley's Short History of the American Negro; in addition to On the Origin of Species by Charles Darwin, Henrik Ibsen's Doll's House, and the complete poetic works of John Milton. ${ }^{54}$ The library later added Carter Woodson's The Negro in Our History in $1922 .^{55}$ The branch's offerings afforded African Americans the chance to read both fiction and non-fiction books in one place and to engage in both literature of the white canon as well as the writings of Black intellectuals. Given Blue's intellectual affinity for Washington and Du Bois, it was only natural the first book checked out from the Western Branch Library was Booker T. Washington's Up From Slavery, a quintessential work on social advancement, education, and making oneself in the broader American society. ${ }^{56}$

The same varied selection of titles and genres could be said for the Children's Section, too. Aesop's Fables, Arabian Nights, Rudyard Kipling's Jungle Book, and many other fairy tales lined the bookshelves. Guides and handbooks on scouting, children cookbooks, and classroom primers provided civic, social, and educational resources for black children. ${ }^{57}$ The Children's Booklist was geared equally to both boys and girls in terms of subjects, genres, and reading age. Between these two booklists, Reverend Blue stressed learning and education to help African American in their plight

\footnotetext{
53 “Adult Booklist," n.d., Reverend Thomas F. Blue Papers, Louisville Free Public Library.

${ }_{55}^{54}$ Ibid., 1-5.

${ }^{55}$ Thomas Fountain Blue, “A Successful Library Experiment,” Opportunity (August 1924): 245.

${ }^{56}$ Louisville Times, September 28, 1905.

57 “Juvenile Booklist," n.d., Reverend Thomas F. Blue Papers, Louisville Free Public Library.
} 
against social and racial discrimination through existing structures of education and learning institutions. He noted the library served "as a social and educational center" for the African American community "as a continuation of school.." ${ }^{, 58}$ Blue's community center approach integrated the activism of racial uplift with the educational efforts of the library into one communal, shared meeting space. ${ }^{59}$ The interconnectivity of the school and the library for Blue stemmed from the emphasis placed on education by Washington and Du Bois.

From his post in the library, Reverend Blue continued to engage in social activism within the profession. In a speech entitled "Making the Library Known to the Community," Blue expressed three areas of focus for "colored libraries." In this speech delivered at Fisk University in Nashville, Tennessee, a historically black university, Blue's first concern dealt with access and location of the library. As a library catered to a certain portion of the populace, the library needed to be geographically close to its users. In Louisville, the two Colored Branches sat in Black neighborhoods. However, on a trip to a similar library in the South, in which the "colored library" was housed within a white library, Blue additionally lamented that the one room for blacks "contained a small collection of books," which were in poor condition. Likewise, the "magnificent Carnegie building" was "in an exclusively white residential section [of the city,] far away from the masses of colored readers." ${ }^{60}$ For Blue, creating a library for

\footnotetext{
${ }^{58}$ Thomas Fountain Blue, "On the Library as an Aid to Public Instruction," n.d., Reverend Thomas F. Blue Papers, Louisville Free Public Library. ${ }^{59}$ Mervin Aubespin, Kenneth Clay, and J. Blaine Hudson, Two Centuries of Black Louisville (Louisville, Kentucky: Butler Books, 2011), 60.

${ }^{60}$ Thomas Fountain Blue, "Making the Library Known to the Community," Negro Library Conference, Fisk University, Nashville, TN, November 20-23, 1931, Reverend Thomas F. Blue Papers, Louisville Free Public Library.
} 
colored readers was a start, but placing that library in a section of a city with little to no black residents represented poor planning on the part the library's leadership and resulted in a disservice to prospective users.

Blue's second concern called for adequate equipment at the library. It stood to reason "a poor collection of books is unsuitable, uninviting" to patrons. ${ }^{61}$ Moreover, "unattractive quarters with an untrained, tactless attendant[s] in charge will not invite attention or create much interest" for users. ${ }^{62}$ In addition to a large and varied collection, Blue called for "movies, radios, and other countless attractions" to stimulate the mind and senses of its patrons as the best way to "make itself known and [be] sought by the people of the community." ${ }^{93}$ Blue wanted to educate the illiterate and provide the means to do so. As Blue reasoned, if the community was not excited and interested in the services of the library, the library turned into a stagnant repository of books. A library depended on users engaging its resources. Without patrons checking books out, using the reference collections, or using the space for learning, the library ceased to function as it was designed. If none inhabited the library and mined its materials, it turns into a building of sheltered bookcases.

Additionally, Blue expressed concern over "efficient service" at the Western Colored Library. Without adequately meeting patrons' needs, the library failed in its mission. By meeting the services required by patrons, a user turned into a satisfied customer and "a satisfied customer is considered the best advertisement" for the library

${ }^{61} \mathrm{Ibid}$.
${ }^{62} \mathrm{Ibid}$.
${ }^{63} \mathrm{Ibid}$. 
and its services. ${ }^{64}$ In Blue's opinion, word-of-mouth advertisement by library users could draw other patrons when they learned of the types of programming, services, and books at the library. As with any business selling goods or services, in "the public library[,] the objective should be a satisfied customer, and the same results will be attained" over again. ${ }^{65}$ Blue's language of "customers" acknowledged his understanding of library patrons as part of the larger process of achieving racial equality in society through the educational process. In order for that business to thrive, there must be people actively using the library and its resources. The language employed by Blue also echoed the social uplift envisioned for blacks using the library. A patron was viewed as anyone able to use its services, but a customer, by contrast, had the luxury and ability to use the services of the library. To Blue, the library represented a fundamental support for the uplift of blacks in providing an area to freely educate many people.

Most of Blue's professional writings dealt with education, librarianship, and access for African Americans. An ethical, cautious, and driven man, Blue left the philosophical rhetoric to the national figures like Washington and Du Bois, who he felt were better equipped to proselytize the national message of social uplift through education. Blue felt they held greater national exposure on these issues than he did as they - through their eloquent speeches and lyrical writing - could promote the message better and with greater impact. While the two of them spread the message nationally, Blue relished in his local role and worked on that level laying the groundwork for their national ideas to take root.

64 Ibid.

${ }^{65}$ Ibid. 
Blue's dedication to his work led him to shun many of the personal accouterments of life in order to pursue the building of the library and expand its influence in the city. In August 1924, however, he met Miss Cornelia Phillips Johnson of Columbia, Tennessee. Johnson was visiting Louisville at the time and they met through mutual friends. On June 18, 1925, they were married; the groom being 59 years old. ${ }^{66}$ Blue's devotion to expanding the outreach of the library into the African American community put other life choices on hold, until there was time to fully devote to them.

In a paper delivered at the Hampton Institute at a library conference, Blue argued libraries should be used as community centers for its residents in the area. Citing how Louisville's two colored libraries each offered community rooms which were "free from unwholesome influence" by outside agitators. ${ }^{67}$ Blue continued with "the fact that during a single month ninety-three meetings for educational and social uplift have been held" between the two libraries. ${ }^{68}$ Of the ninety-three meetings, social groups like the Urban League, the Inter-Racial Committee, and the Community Chest Committee organized many. ${ }^{69}$ These organizations would be left without meeting spaces if the community rooms in the libraries were not available. The public library system in Louisville offered many amenities to African Americans compared to other cities in the South.

\footnotetext{
${ }^{66}$ Wright, 8.

${ }^{67}$ Thomas Fountain Blue, "The Library as a Community Center," paper delivered at Library Conference at Hampton Institute, March 15-18, 1927, Reverend Thomas F. Blue Papers, Louisville Free Public Library.

${ }^{68}$ Ibid.

${ }^{69}$ Ibid.
} 
Though not as liberal as many cities in the North, Louisville exhibited some progressive tendencies not often expressed in the Deep South. Under Blue's direction, Louisville Public Library system offered apprentice-training courses for future black librarians. ${ }^{70}$ Beginning in 1912, this two - six month course offered the only formalized training "for prospective black librarians in the South until the Hampton Library School opened in Virginia in 1925."71 By 1924, thirty-seven people had completed the program. Designed by Reverend Blue, the apprentice class "conducted and [gave] instructions in library methods" to those perusing careers in the library. ${ }^{72}$ Through this course, students learned basic library science techniques, methods of collection, organization, and research assistance. Students completing the course often stayed in Louisville and worked at either of the colored branches. There were several students sent to Louisville for specifically this training from places across the South. The cities of Atlanta, Georgia; Birmingham, Alabama; Memphis, Nashville, Chattanooga, and Knoxville, Tennessee; Evansville, Indiana; and Houston, Texas all sent black library personnel to Louisville for Blue's librarian apprenticeship training. Once they completed the course, they returned to their city to implement the skills and methods acquired from Blue. ${ }^{73}$ For completion of the course by his students, successful students understood "the business of the librarian is not to know everything in all the books in the

\footnotetext{
70 “The Colored People's Libraries of the South," Journal of Blacks in Higher Education 32 (Summer 1948): 44.

${ }^{71}$ Fultz, 341.

72 Blue, “A Successful Library Experiment," 246. Blue's library apprentice course continued until 1931.

${ }^{73}$ Ibid.
} 
library" but rather "know what is in the library and how to find it." ${ }^{, 74}$ Libraries contain vast materials and resources. Blue did not want his students to simply know every title contained in the library. That benefitted no one. For Blue, understanding how to local books, reference collections, or other information was the true function and role of librarian. The librarian acted as a compass to the patrons in pointing them in the direction of the material that they sought.

Blue's approach to library administration and influence soon spread throughout the South. One of the first methods learned in his apprenticeship course involved properly selecting books for the library. One of Reverend Blue's closest assistants at the Western Library, Rachel Harris, was in charge of the children's books at the library. Owing to the maternal nature of child rearing and education, Blue felt a woman was best to oversee the administration of the children's department by a woman. Hired shortly after the opening the Western branch, Harris was a longtime employee of Blue's and his most trusted associate. Through their combined years and experience, other black librarians in the South recognized Harris and Blue as experts on selecting and building collections for black library patrons. ${ }^{75}$ In 1919, the two compiled and distributed "A List of Books Selected from Titles in the Western Colored Branch of the Louisville Free Public Library Recommended for First Purchase," a collection of book titles to serve as a guide for a "core collection not unlike those at public libraries across the country."

\footnotetext{
${ }^{74}$ Thomas Fountain Blue, "Library Training Class notes: Classification and Arrangement of Book," Reverend Thomas F. Blue Papers, Louisville Free Public Library.

${ }^{75}$ Cheryl Knott Malone, "Books for Black Children: Public Library Collections in Louisville and Nashville, 1915-1925," Library Quarterly: Information, Community, Policy (April 2000): 183.

${ }^{76}$ Ibid., 184.
} 
When the Nashville Colored Library Branch opened in 1916, Blue and Harris' collection served as the basis for selecting titles for the new Nashville library. ${ }^{77}$

The infrastructure and operation developed by Blue at "Louisville's black libraries became regional models" for others to follow. ${ }^{78}$ Under Blue's leadership from 1905 - 1935, the Colored Department expanded considerably - the construction of two Carnegie libraries in 1908 and 1914, the establishment of over forty school library collections among eleven schools, and at least ten library stations scattered across town for residents to use. ${ }^{79}$ These library collections gave students classroom-access to books, magazines, and other educational materials without having to make the trip to the Colored Library. These satellite libraries were small collections of materials inside a single classroom, and each teacher was responsible for overseeing the collection and the administration of lending books to the students.

Likewise, the ten library stations scattered across town reflected Blue's vision of providing educational means to the greatest number of people possible. These scattered collections were in people's homes, in small corner stands at a street intersection, or a neighborhood church. By placing more books out in the public, residents had greater access to these materials than if they were simply kept at the colored libraries. ${ }^{80}$

\footnotetext{
77 Ibid., 186

${ }^{78}$ Fultz, 340.

${ }^{79}$ Wright, 20.

${ }^{80}$ Ibid.
} 


\title{
BLUE'S LEGACY:
}

\section{THE COLORED DEPARTMENT AS A SYNTHESIS OF BOOKER T.}

\author{
WASHINGTON AND W.E.B. DU BOIS
}

On Wednesday, November 6, 1935, Reverend Thomas Blue became ill. Over the course of the next four days, his condition slowly deteriorated. At 9:05 p.m., Reverend Blue passed away; he was 69 years old. ${ }^{81}$ In a statement at their meeting, the Board of Trustees at the Louisville Free Public Library, the all-white overseeing body of the Louisville Free Public Library's Colored Department, noted Blue's civic and profession service to the Library as a "respected leader in the civic, religious and educational life of the colored people" in the city. ${ }^{82}$

Since becoming the head of the Colored Department, Blue worked vigorously in broadening educational outreach and resources to people of color. Blue commented:

The library does more than just furnish facts and circulate books. With its reading and study rooms, its lecture and classrooms, it forms a center from which radiates many influences for general betterment. Aside from circulating books, and furnishing facts in reference work, the library encourages and assists all efforts to an educational end, and the advancement of our [colored] people in this city. ${ }^{83}$

\footnotetext{
${ }^{81}$ Wright, 45.

${ }^{82}$ Louisville Free Public Library Board of Trustees, "Resolution," Board meeting on November 20, 1935, Reverend Thomas F. Blue Papers, Louisville Free Public Library. 83 "Title Spotlight: Reverend Thomas Fountain Blue," Kentucky Libraries 67 (Fall 2003): 6-7.
} 
Mirroring the work of contemporary Booker T. Washington, Blue's

understanding of the library and its resources of education as a way to advance the social welfare of African Americans. As noted by Blue, the "general betterment" of African Americans in Louisville came about through the Colored Department at the Louisville Free Public Library. ${ }^{84}$ Like Washington, Blue advocated for the advancement of African Americans through education as the main means for social uplift and equality in American society.

Expounding on Washington's ideas of education, Blue developed the Douglas Debating Club in March 1909. ${ }^{85}$ The club consisted of black male high school students. At the club, these young men gained "parliamentary usages, to keep before them the great current questions" of the time, "and to train them to speak in public." 86 The members were better prepared to engage in the public discourse following their membership in the Club. Starting as an offshoot to Washington's ideas of education, the Club soon became more aligned with Du Bois' notion of the Talented Tenth with smart, educated, and trained men to propagate social uplift into African American society. The education in the Douglas Debating Club both trained and equipped the young men with life skills for after graduation. ${ }^{87}$

In other ways, Reverend Blue also employed the ideas of W.E.B. Du Bois' Talented Tenth. Through is library apprenticeship course, Blue produced more learned, professional, and upstanding members to the Tenth. Those professionals who finished the course found work in other libraries in the South and implemented the ideas

84 "Title Spotlight," 6-7.

${ }^{85}$ Blue, "Making the Library Known to the Community."

${ }^{86}$ Ibid.

${ }^{87}$ Ibid. 
espoused by Blue. George T. Settle, head librarian at the Louisville Free Public Library, articulated it best saying students in the course had to have "a high school education... fair knowledge of books, good health, courteous manner, neatness in appearance and in work, accuracy, speed, reliability, general intelligence and good judgment." ${ }^{98}$ Settle's description of the students in the apprenticeship program mirrored the language Du Bois used for his Tenth.

The early Black Nationalists of Washington and Du Bois stressed social uplift by educating a new generation of African Americans that their minds, intuitions, and ideas were just as important and powerful as whites. ${ }^{89}$ By advancing, strengthening, and promoting the Colored Department at the Louisville Free Public Library during his time with the Library, Reverend Thomas Blue represented a continuation of Washington and Du Bois' legacy as he championed social advancement and racial equality through the library's services in Louisville and in the nation.

\footnotetext{
${ }^{88}$ George T. Settle, "Examination for Admission to the Library Service in the Colored Branch," n.d., typescript in the African-American Historical Archives, Louisville Free Public Library.

${ }^{89}$ Beginning in the 1910s, Jamaican-born Pan-Africanist activist Marcus Garvey spoke of racial uplift for men and women of African descendant who felt alienated by whites on the basis of race and by the black elites on the basis of class. Mostly influential in large, urban centers like New York and New Orleans, Garvey's ideas did not fully permeate into the interior of the United States like Washington or Du Bois; although Garvey did speak on several occasions in Louisville. All three men - Washington, Du Bois, and Garvey - differed in style and approach when it came generating the social uplift of African Americans in American society, but Washington and Du Bois' ideology most resonated in Louisville. For a better analysis on Garvey, see Adam Ewing, The Age of Garvey: How a Jamaican Activist Created a Mass Movement and Changed Global Black Politics (Princeton, NJ: Princeton University Press, 2014).
} 


\section{REFERENCES}

Aubespin, Mervin, Kenneth Clay, and J. Blaine Hudson. Two Centuries of Black Louisville. Louisville, Kentucky: Butler Books, 2011.

Blue, Mary E. Letter to Thomas F. Blue, Jr. June 16, 1953.

Blue, Thomas Fountain. “A Hamptonian as Librarian.” Southern Workman 52 (July 1923): 368-369.

. "Address at the Fiftieth Anniversary of the founding of

Wayland Institute," delivered in Washington D.C. and Richmond Theological Seminary, Richmond, VA, June 2, 1915.

. "Adult Booklist." N.d.,

. "Colored Branch Library Work in Louisville" N.d.

. "Farewell Address" delivered at Hampton Institute, 1888.

. “Juvenile Booklist." N.d.

. "Library Training Class notes: Classification and Arrangement

of Book." N.d.

. "Making the Library Known to the Community." Negro

Library Conference, Fisk University, Nashville, TN, November 20-23, 1931.

. "On the Library as an Aid to Public Instruction." N.d.,

. "Public Library Work Among Colored People" N.d.,

. "The Library as a Community Center." Paper delivered at Library Conference at Hampton Institute, March 15-18, 1927. 
. Annual Report of the Western Colored Branch for the Year

Ending August 31, 1913.

. Southern Workman 47 (July 1918): 367-368.

. "A Successful Library Experiment." Opportunity (August

1924): 244-248.

. Annual Report of the Board of Trustees of the Louisville Free

Public Library for the Year Ending August 31, 1906.

"The Colored People's Libraries of the South," Journal of Blacks in Higher Education 32 (Summer 1948): 44-45.

Dewey, Melvil. A Classification and Subject Index for Cataloguing and Arranging the Books and Pamphlets of a Library. Amherst, Massachusetts: 1876.

Du Bois, W.E.B. ed., The Negro in Business: Atlanta University Publications, No. 4 (Atlanta, 1899).

, "The Talented Tenth," in The Negro Problem: A Series of Articles by Representative American Negroes of To-Day. (New York: James Pott \& Co., 1903.

. "The Talented Tenth: Memorial Address." Boulé Journal 15 (October 1948): 347-353.

Fultz, Michael. "Black Public Libraries in the South in the Era of De Jure Segregation." Libraries \& the Cultural Record 41 (Summer 2006): 337-359.

Gilbert, Felix, and David Clay Large, The End of the European Era, 1890 to the Present New York: W.W. Norton, 1991.

Harlan, Louis R. Booker T. Washington: The Making of a Black Leader, 1856-1901. New York: Oxford University Press, 1972. . Booker T. Washington: The Wizard of Tuskegee, 1901-1915. New York: Oxford University Press, 1983. 
Jackson, Jr., David H. Booker T. Washington and the Struggle Against White

Supremacy: The Southern Educational Tours, 1908-1912. New York: Palgrave Macmillan, 2008.

Jones, Thomas Jesse. Negro Education: A Study of the Private and Higher Schools for Colored People in the United States. 2 Vols. Washington, D.C.,: United States Bureau of Education, 1917.

K'Meyer, Tracy E., Civil Rights in the Gateway to the South: Louisville, Kentucky 19451980 Lexington, Kentucky: University Press of Kentucky, 2009.

Lewis, David Levering. ed. W.E.B. Du Bois: A Reader. New York: Henry Holt and Company, 1995.

Lofgren, Charles A. The Plessy Case: A Legal-Historical Interpretation. New York: Oxford University Press, 1987.

Louisville Free Public Library Board of Trustees, "Resolution,” Board meeting on November 20, 1935.

Louisville Free Public Library. Colored Branch, Louisville Free Public Library: A Brief Illustrated Description of the New Building Together With Some Interesting Figures Concerning Its Cost, Its Equipment, and Its Use. Louisville, Kentucky: 1912.

Louisville Herald, December 7, 1905.

Louisville Times, September 28, 1905.

Malone, Cheryl Knott. "Books for Black Children: Public Library Collections in Louisville and Nashville, 1915-1925." Library Quarterly: Information, Community, Policy (April 2000): 179-200. . "Louisville Free Public Library's Racially Segregated Branches, 1905-1935." Register of the Kentucky Historical Society 93 (Spring 1995): 159179.

Mjagkij, Nina. Light in the Darkness: African Americans and the YMCA, 1852-1946. Lexington, Kentucky: University Press of Kentucky, 1994. 
Rabaka, Reiland. "W. E. B. Du Bois's Evolving Africana Philosophy of Education." Journal of Black Studies 33 (Fall 2003): 399-449.

Settle, George T. "Examination for Admission to the Library Service in the Colored Branch." N.d.

“Title Spotlight: Reverend Thomas Fountain Blue," Kentucky Libraries 67 (Fall 2003): 6-7.

Vorenberg, Michael. Final Freedom: The Civil War, the Abolition of Slavery, and the Thirteenth Amendment. New York: Cambridge University Press, 2001.

Washington, Booker T. "Address at the banquet of the Young Men's Forum of Cambridge, MA." Quoted in Boston Globe, October 4, 1904. . Up From Slavery. New York: Airmont Books, 1967.

Wiegand, Wayne A. Part of Our Lives: A People's History of the American Public Library. New York: Oxford University Press, 2015.

Wright, Lillian Taylor. "Thomas Fountain Blue: Pioneer Librarian, 1866-1935." Masters thesis. Atlanta University, 1955. 


\section{CURRICULUM VITAE}

NAME:

ADDRESS :

DOB:

EDUCATION

\& TRAINING:
Jacob Carlton Burress

5011 Invicta Drive

Louisville, Kentucky 40216

Louisville, Kentucky - December 6, 1989

B.A., History

University of Louisville

Spring 2012

M.A., History

University of Louisville

Spring 2016

Public History Graduate Assistant, History Department

University of Louisville

Fall 2015 - Spring 2016

Archival Intern, Archives and Special Collections

University of Louisville

Fall 2015

Graduate Online Teaching Assistant, History Department University of Louisville

Fall 2014 - Spring 2015

Planning and Design Intern

Louisville Metro Government

Fall 2013 
PROFESSIONAL SOCIETIES: National Council on Public History (NCPH) 2014-present

NATIONAL MEETING PRESENTATIONS: “Digital Communities: Engaging Public Histories on a New Frontier" (with Katy Morrison), NCPH Annual Meeting, April 2015 